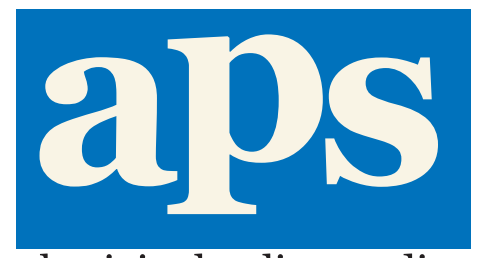

aboriginal policy studies

\title{
Article
}

\section{Finding Your Allies Where You Can: How Canadian Courts Drive Aboriginal Recognition in Canada}

\author{
Ian Peach
}

aboriginal policy studies, Vol. 1, no. 1, 2011, pp. 106-131

This article can be found at:

http://ejournals.library.ualberta.ca/index.php/aps/1/1/Peach.pdf

ISSN: 1923-3299

aboriginal policy studies is an online, peer-reviewed and multidisciplinary journal that publishes original, scholarly, and policy-relevant research on issues relevant to Métis, non-status Indians and urban Aboriginal people in Canada. For more information, please contact us at apsjournal@ualberta.ca or visit our website at

www.ualberta.ca/NATIVESTUDIES/aps/

or

http://ejournals.library.ualberta.ca/index.php/aps/ 


\title{
Finding Your Allies Where You Can: How Canadian Courts Drive Aboriginal Recognition in Canada
}

\author{
Ian Peach \\ University of New Brunswick
}

\begin{abstract}
While it has been valuable to Aboriginal peoples to have the courts as allies in their fight for state recognition, it is worth asking whether the slow, expensive, incremental process of achieving recognition through litigation is really the most efficient, let alone just, policy development process. Métis, Non-Status Indians, and Aboriginal women have all determined that litigation can be a useful strategy for achieving state recognition of their Aboriginality in the face of governmental intransigence. Yet the courts have proven to be imperfect, inconsistent, and not always reliable allies. This article reviews the cases in which Aboriginal women, Non-Status Indians, Métis, and urban Aboriginal people have sought to use litigation to drive the reform of rules for the state recognition of Aboriginal peoples in Canada. These cases include not only successful litigation, but also occasions on which resort to the courts has failed, revealing the difficulties and frustrations that Aboriginal peoples can face in having to rely on litigation to change government policy.
\end{abstract}

\section{Introduction}

While it has been valuable to Aboriginal peoples to have the courts as allies in their fight for recognition over the last thirty-odd years, it is worth asking whether the slow, expensive, and incremental process of achieving recognition through litigation (and the several likely rounds of appeals) is really the most efficient, let alone just, policy development process. The courts have proven to be imperfect, inconsistent, and not always reliable allies; Aboriginal people and communities have succeeded in a number of equality rights challenges before the courts, but have also had their equality

\section{aboriginal policy studies, Vol. 1, no. 1, 2011}

ISSN: 1923-3299 
rights claims denied in a number of other cases, and not always for the most compelling of reasons. Even success generally has led only to the most minimal adaptations of government policy to bring it in line with judicial decisions.

This article is a review of the case law in which Aboriginal women, non-status Indians, Métis, and urban Aboriginal people have sought to use the equality rights provisions of section 15 of the Canadian Charter of Rights and Freedoms (the Charter), as well as Métis Aboriginal rights litigation, to drive the reform of rules for the state recognition of Aboriginal peoples in Canada. These cases are examples not only of the successes that these diverse groups, who share state denial of their Aboriginality, can achieve in using the courts to secure the recognition of Aboriginal peoples by the state. These are also examples of the occasions when resorting to the courts fails, and of the difficulties and frustrations that groups can face when they have to rely on litigation to change government policy and to secure equality for themselves with onreserve First Nation people and communities.

\section{Off-Reserve First Nation Members and the Fight for Equality}

First Nation members who reside off reserves are one group that has used the courts effectively to advance equality for Aboriginal peoples denied state recognition . Because access to most Aboriginal-specific programs and services, funded by the federal government, remains restricted to reserve residents, they remain unequal when compared to their fellow members who reside on reserves. However, they now have rights to political participation in the governance of their First Nations, which they had previously been denied, because of their effective use of the courts.

There are four key cases to date in which the use of the reserve boundary to limit participation in First Nations governments has been challenged as contravening the equality rights of off-reserve members. The first case, decided by the Supreme Court of Canada in 1999, was Corbiere v. Canada (Minister of Indian and Northern Affairs), ${ }^{1}$ a challenge to those Indian Act provisions that limited the right to vote for chief and council of an Indian band to reserve residents, that began with a Federal Court decision in 1994. Corbiere remains an important decision for the equality rights of offreserve status Indians, as the court, in two concurring judgments, decided 
that the provision that denied off-reserve status Indians the right to vote in band elections was discriminatory and could not be saved by section 1 of the Charter. Most importantly, this decision established Aboriginalityresidence as a ground upon which an identifiable group of people can suffer discrimination, analogous to those grounds listed in section 15 of the Charter. On this issue, the court concluded that the Aboriginality-residence distinction is a personal characteristic essential to a band member's personal identity, and which is, thus, changeable only at an unacceptable cost to their personal identity. ${ }^{2}$

In their judgment in this case, McLachlin and Bastarache JJ. stated that,

Taking all this into account, it is clear that the s. 77(1) disenfranchisement is discriminatory. It denies off-reserve band members the right to participate fully in band governance on the arbitrary basis of a personal characteristic. It reaches the cultural identity of off-reserve Aboriginals in a stereotypical way. ... This engages the dignity aspect of the s. 15 analysis and results in the denial of substantive equality. ${ }^{3}$

The next case to raise the issue of discrimination based on Aboriginality-residence directly, Francis v. Mohawk Council of Kanesatake, ${ }^{4}$ decided by the Federal Court, Trial Division in 2003, was also a voting rights case. The difference in this case was that the Mohawk Council of Kanesatake was elected pursuant to a band custom election code, authorized by the Indian Act, rather than to the general Indian Act band election rules. While the Federal Court, Trial Division, decided that it was not necessary to determine whether the exclusion of off-reserve band members from voting under band custom election codes violated section 15 of the Charter, the court did note that,

Recent indications in the jurisprudence of the Federal Court of Canada show a certain inclination towards the applicability of the Supreme Court's decision in Corbiere, supra, to custom band elections [citations deleted]. However, in none of these decisions did the Court engage in any kind of extensive analysis of the "complex" legal issues involved in determining whether Corbiere, supra, also applied to custom band elections. I think this question 
is still open to debate and the indications already given by the Court are by no means definite. ${ }^{5}$

This question was resolved two years later, at least at the level of the Federal Court, Trial Division, in the case of Clifton v. Hartley Bay (Electoral Officer). ${ }^{6}$ In deciding this challenge to a band custom election code, the Federal Court, Trial Division, quickly found that there was a distinction in the election code based on the analogous ground of Aboriginalityresidence, and that this distinction was discriminatory. Thus, the Federal Court, at least at the level of the Trial Division, has taken the view that the complete exclusion of off-reserve status Indians from voting is a violation of section 15 of the Charter and cannot be justified even in the case in which the exclusion is part of a band custom election code, where, presumably, an argument that the First Nation was exercising a right of self-government could better be made.

The fourth case on the issue of discrimination against off-reserve band members was Esquega v. Canada (Attorney General). ${ }^{7}$ This was a challenge to the Indian Act's exclusion of off-reserve members from standing for election as band councillors. The Federal Court, Trial Division, found the exclusion discriminatory and found that it could not be saved as a reasonable limit on equality, using essentially the same logic as the Supreme Court of Canada did in Corbiere. Consequently, off-reserve band members now also have the right to stand for election as band councilors.

While there have, to date, only been four equality rights challenges of this type, the courts have consistently found restrictions on participation in band politics to be a violation of equality rights under the Charter. These cases have advanced the equality of off-reserve First Nation members, yet they remain discriminated against, most notably in their direct or effective denial of access to programs and services funded by the federal government to which other First Nation members have access. Despite the advances that off-reserve First Nations members have made in the sixteen years since the original Federal Court, Trial Division decision in Corbiere, off-reserve First Nations members still lack full equality with their on-reserve counterparts.

\section{Equality and Recognition of Aboriginal Groups}

Analogous cases have also been brought forward by groups without federal recognition as First Nations, challenging their exclusion from access to, 
or control over, funding directed to Aboriginal peoples as a contravention of their equality rights. The most significant, and in some ways most problematic, of these cases is Lovelace v. Ontario, decided by the Supreme Court of Canada in 2000. ${ }^{8}$ This was an equality rights challenge to Ontario's decision to distribute the profits from Casino Rama, which is on a reserve, to Indian Act bands only, made by members of Aboriginal communities that were not recognized as Indian bands under the Indian Act. The nonstatus complainants lost their equality rights challenge in this case, but Lovelace suffers from serious analytical weaknesses. One weakness, for example, which affected the result in Lovelace, is the rejection of what the court termed a "relative disadvantage" approach in determining if there is discrimination. Justice Iacobucci, for the Court, commented that,

\section{I, therefore, support the Court of Appeal's rejection ... of a relative disadvantage approach. The inappropriateness of such an approach is highlighted by the unique circumstances of this appeal, where we must respectfully acknowledge the disadvantages suffered both by the claimants and the comparator group. Moreover, the remedial and holistic nature of the s. 15(1) inquiry obliges this Court to proceed to the directed contextual analysis from the standpoint of acknowledging severe and profoundly patterned historical disadvantages (see Corbiere, supra, per L'Heureux- Dubé J. at para. 54).}

In short, beyond the unseemly nature of the relative disadvantage approach that is, "pitting one disadvantaged group against another"- Lovelace's narrow focus is inconsistent with the fullness of the substantive equality analysis. ${ }^{9}$

Yet, in Law v. Canada (Minister of Employment and Immigration), ${ }^{10}$ which set out the current test for violations of equality rights only a matter of months before the Lovelace decision, Justice Iacobucci, for the court, had repeatedly used the word "more" as an adjective to modify the word "disadvantaged." He stressed that,

in referring to groups which, historically, have been more or less disadvantaged, I do not wish to imply the existence of a strict dichotomy of advantaged and disadvantaged groups, within which each claimant must be classified. I mean to identify simply 
the social reality that a member of a group which historically has been more disadvantaged in Canadian society is less likely to have difficulty in demonstrating discrimination. ${ }^{11}$

Justice Iacobucci also commented in Lovelace that, "one must recognize that exclusion from a targeted or partnership program is less likely to be associated with stereotyping or stigmatization or conveying the message that the excluded group is less worthy of recognition and participation in the larger society." 12 It is difficult to understand how the targeted nature of a program makes it less stigmatizing to exclude a group that shares the disadvantages of the group targeted for the benefit but also suffers additional disadvantages, due to stereotyping as being "less Aboriginal" than the Aboriginal group that benefits from the program.

The Court relies on this weak analysis to conclude that, applying the contextual factors discussed above, I find that the appellants have failed to demonstrate that, viewed from the perspective of the reasonable individual, in circumstances similar to those of the appellants, the exclusion from the First Nations Fund has the effect of demeaning the appellants' human dignity. ${ }^{13}$

On the other hand, the Federal Court of Appeal came to the opposite conclusion about the exclusion of groups that were not affiliated with the Assembly of First Nations, the Métis National Council, or the Inuit Tapirisat of Canada (i.e., non-status or off-reserve Indian organizations) from being signatories to federal Aboriginal Human Resources Development Agreements (AHRDAs), in its decision in Misquadis v. Canada (Attorney General). ${ }^{14}$ As the primary benefit of the Aboriginal Human Resources Development Strategy (AHRDS) was characterized as local community control over an Aboriginal human resources development program, the claimants argued that their exclusion from participation in the AHRDS, and therefore their exclusion from participation in program design and management, constituted discrimination in comparison to those Aboriginal organizations that were chosen to be agreement signatories. The Federal Court of Appeal determined that the distinction made by Human Resources Development Canada in excluding off-reserve and non-status Indian groups from participation in AHRDS was based on the well-established analogous ground of "Aboriginality-residence," first identified in Corbiere..$^{15}$ The Court 
of Appeal concluded in this case that there was discrimination contrary to section 15 of the Charter, and that this discrimination could not be saved by section 1 of the Charter. ${ }^{16}$

Despite this decision in Misquadis, the Federal Court, Trial Division, came to the opposite conclusion in Micmac First Nation v. Canada (Minister of Indian and Northern Affairs), ${ }^{17}$ decided in 2007. In this case, members of the Micmac Nation of Gaspeg brought an equality rights challenge to the exclusion of students who were members of the Nation (which does not have a reserve) from access to the financial assistance that the federal government provides to bands for students who reside on reserves but attend elementary or secondary schools off-reserves. ${ }^{18}$ Justice Martineau commented that,

I note that in Corbiere, above, the Supreme Court recognized that members of First Nations bands living off-reserve are vulnerable to unfair treatment because a stereotype has been attached to this group that its members are "less Aboriginal" than band members who live on reserves. Based on the evidence in the record, it is clear that a landless band suffers real disadvantages considering the position that the group and its members occupy in the social, political and legal contexts of our society. . . . In this case, the fact of being a member of a landless band, which includes Band students for purposes of examining the legality of the Program's impugned provisions, is a personal characteristic. It is immutable or difficult to change. ${ }^{19}$

Yet, despite this, the court refused to decide whether the band members could claim the analogous ground of Aboriginality-residence because the court concluded that, even if there was a distinction based on an analogous ground, there was no discrimination. ${ }^{20}$ The key to why it arrived at this conclusion may lie in the court's "ameliorative purpose" analysis, which hearkens back to the faulty logic of the Lovelace decision. On this point, the court stated that,

In this case, the Program is one of the targeted federal ameliorative programs designed to address the unique challenges faced by First Nations members living on reserves or Crown lands. From the evidence in the record, it is clear that the primary objective of 
the Program is to reduce the education gap that affects students who live on reserves or Crown lands by allowing them to benefit from services and programs comparable to those available to other students in the same province or area of residence.... The evidence in the record also shows that the secondary school enrolment rate is lower than the national average for First Nations members who live on reserves. ${ }^{21}$

It is not clear from the decision, however, that the federal program merely provided funds to First Nations for services that were provided to other students by the provincial governments. If this were the case, it may be that an equality rights claim should fail, as all students would have equal access to programs and services. If, however, the federal program provided on-reserve students with services not provided to other students, a different situation would arise. The mere fact that a program ameliorates the condition of someone who suffers a disadvantage is, on a careful reading of Law, inadequate to ground a finding that there is no discrimination at work in an underinclusive program. Rather, there must be a finding that the program ameliorates the condition of someone or some group worse off in a relevant way than the claimant group. If off-reserve Indians, in fact, have higher rates of school achievement than those on-reserve, the ameliorative purpose test could justify the court's finding that there was no discrimination in this case. However, there is no indication in the judgment that there was any evidence before the courts to this effect. In the absence of a valid ameliorative purpose, it would seem to be difficult not to find discrimination.

While cases such as Misquadis certainly have done something to advance the equal treatment of different Aboriginal groups, the inconsistency among these decisions, and the problematic analysis used to arrive at the results in the cases that the Aboriginal claimants lost, points to a key problem with using litigation to drive Aboriginal policy in this country. Because courts are tasked with deciding particular conflicts in particular circumstances that come before them at particular times, litigation does not always lead even to a consistent incremental advance in a particular direction. Instead, the outcome of litigation can often be significantly affected by the particulars of the fact situation, conclusions can be factspecific and therefore of limited utility in developing a set of principles that could guide policy development, and decisions can sometimes even be fact- 
driven. In the case of equality between groups recognized as First Nations and Aboriginal groups not so recognized, the fourteen years of litigation since the original Ontario Superior Court decision in Lovelace in 1996 may have left governments more confused than ever about what is, and is not, consistent with the equality rights of Aboriginal peoples.

\section{Aboriginal Women, Indian Status, and Equality}

Moving on to a third group of cases, individuals who have been denied "Indian status" under the Indian Act have been effective in using the courts, and equality rights litigation in particular, to influence the federal government's Aboriginal policy in a way that reduces discrimination. Non-status Indians, Métis, and First Nations people have all turned to the courts in an attempt to bring an end to the discriminatory distinctions among Aboriginal individuals on the basis of status, with many of these cases having been brought by Aboriginal women who have been denied status themselves or are unable to pass status onto their children and grandchildren. These challenges, or the threat of challenges, began even before section 15 of the Charter came into force in April of 1985. The overt gender discrimination in the status rules of the 1951 Indian Act was brought before the United Nations in 1981 by an Indian woman, Sandra Lovelace, who had lost her status upon marriage. ${ }^{22}$ Between this challenge and the inclusion of the new Canadian Charter of Rights and Freedoms, which included equality rights, in the Canadian Constitution in 1982, the Government of Canada realized that the overt gender discrimination in the Indian Act would need to be altered. To address this issue, the government introduced Bill C-31. While the bill removed the most overt gender discrimination in the Indian Act status rules, discrimination between status and non-status Indians continued, often due to the gender discrimination that existed in previous versions of the Indian Act.

One of the first cases in which an individual sought to use section 15 of the Charter to secure equal treatment with status Indian band members was Scrimbitt v. Sakimay Indian Band Council. ${ }^{23}$ In this case, Scrimbitt was a member of the Sakimay First Nation who married a non-Indian in 1971 and then lost her status, but who regained her status under Bill C-31. She was then struck from the Sakimay band list and not allowed to vote in band elections due to the operation of the band's membership code, which was designed to disenfranchise potential band members who had received status 
by the operation of Bill C-31. She challenged this exclusion as incompatible with section 15 of the Charter and won. The Federal Court, Trial Division, decided that the refusal of the right to vote discriminated against Ms. Scrimbitt, and was based on sex and marital status, which are immutable characteristics. ${ }^{24}$ It also determined that refusing Ms. Scrimbitt the right to vote was an affront to her dignity, ${ }^{25}$ and so the refusal contravened section 15 of the Charter. ${ }^{26}$

A similar challenge was brought in the case of Grismer v. Squamish First Nation. ${ }^{27}$ In this case, the adult adopted children of a Squamish First Nation member were denied membership because of the rules of the First Nation's membership code. This code established three categories of members: descendant members, lineal members, and acquired members. ${ }^{28}$ Lineal members, the class under which the claimants sought to become members, require that applicants have a biological parent who is a Squamish First Nation member. ${ }^{29}$ Acquired members are primarily minor children with Indian status who have been adopted by two Squamish parents..$^{30}$ Because the First Nation member parent of the claimants was only their adoptive parent, the claimants were denied the status of lineal members and, because the claimants were over eighteen in this case, they were also denied acquired membership..$^{31}$

In deciding this case, the Federal Court, Trial Division, decided that an infant cannot change their status as an adopted child, making it an immutable characteristic, while the adoption status of an adult child is constructively immutable..$^{32}$ As a consequence, the status of adopted child qualifies as an analogous ground. ${ }^{33}$ The court then went on to decide that, while the Squamish First Nation had the right to develop its own membership code, its provisions discriminated between adopted and biological children, as well as among adopted children themselves..$^{34}$ Thus, the court found that paragraph 7(b)(i) of the Squamish First Nation membership code was contrary to section 15 of the Charter.

The court, however, went on to find the code to be justified under section 1 of the Charter, which provides governments the ability to justify reasonable limits on rights, due to the existence of the acquired membership provisions. The First Nation described this provision as a "compromise" arrangement to make provision for adopted children and felt that to go further and include a provision for the adopted child of only one Squamish parent would unduly stretch Squamish laws and traditions. ${ }^{35}$ The court concluded that 
[c]onsiderable deference should be accorded to the Squamish in making this policy decision, particularly since it concerns questions of citizenship, Band custom and lineage ... .

In my opinion, in the case at bar, the "compromise" arrangement provided for in the Membership Code minimally impairs any rights that may exist for non-Squamish adoptees, while still achieving the objective of protecting Squamish culture and identity through traditional means. ${ }^{36}$

The court did, however, note that, "in another case, based on a differently constituted evidentiary record, another judge may have come to a different conclusion" on the issue of whether an infringement is justified. ${ }^{37}$

One interesting case in this group of cases, Ochapowace Indian Band v. Saskatchewan (Department of Community Resources), ${ }^{38}$ was a challenge by Chief Denton George of the Ochapowace First Nation to a provision of Saskatchewan's child and family services legislation. The provision in question was one that allowed the chief of a band to be designated as a "person of sufficient interest" to be a party to child adoption proceedings in cases in which a status Indian child was being adopted, but not in cases in which a non-status Indian child who was or had a right to be a band member was being adopted. The Saskatchewan Court of Queen's Bench decided that the distinction identified by Chief George between status and non-status Indian children did not constitute discrimination. To come to this conclusion, however, the court redefined the groups being compared, replacing the proposed comparison between status and non-status Indians with a comparison between Aboriginal and non-Aboriginal children, despite the fact that the distinction made in the Saskatchewan legislation is specifically between status Indians and all other children, even those who are Aboriginal but non-status. In redefining the comparator group, the court stated that,

For practical reasons, the designation [of a chief as a person of sufficient interest] is provided for status Indians as defined in the Indian Act. This is a practical limitation but not a reflection of or a comment on any relative historical disadvantage of status Indians vis-a-vis non-status Indians. Thus, the benefit conferred is directed toward Aboriginal communities as compared to non- 
Aboriginal communities, and not status Indians as compared to non-status Indians. ${ }^{39}$

This determination is difficult to understand, as the provision to designate a chief as a person of sufficient interest is not available in cases involving Aboriginal children who do not have status, even if they are children who are or have a right to be band members.

The Court went on to determine that,

underinclusivity does not violate the purpose of the Charter. Underinclusivity in this context may include both s. 23(1)(b)'s failure to address non-Aboriginals and its failure to address nonstatus Indians. In either event, the ameliorative objective can only be met if s. 23(1)(b) can be put to practical use. The provision has no practical use if it treats Aboriginals and non-Aboriginals the same. It treats Aboriginals and non-Aboriginals differently precisely for the reason that treating Aboriginals and nonAboriginals the same would not lead to a fair result. Likewise, it is not practical to expect the Courts to determine who is and who is not an Aboriginal, without the assistance of the Indian Act, and therefore it is not discriminatory to exclude non-status Indians from the application of the provision because to do otherwise would lead an unworkable system. ${ }^{40}$

Of course, the issue in this case is not that section 23(1)(b) of the provincial legislation treats Aboriginal and non-Aboriginal people differently, but that it treats some Aboriginal people differently than others. Underinclusivity that serves to exclude a group that has suffered greater disadvantage than the group that receives the benefit provided by the law, such as non-status Indians in comparison to status Indians, is inconsistent with the principle that government may not provide a benefit to some in a way that discriminates on a ground prohibited under s. 15 of the Charter. Equally, the assertion that it is not practical to expect the courts to determine who is and who is not Aboriginal in this case is both irrelevant, as there seems to have been no dispute that the child in question was Aboriginal, and inconsistent with the Supreme Court of Canada's decision in the Powley case ${ }^{41}$ in which the Court did establish a guide for determining Métis identity because it did not have recourse to any pre-existing legal definition. The Court of Queen's Bench's 
decision was upheld on appeal on technical grounds, but the Saskatchewan Court of Appeal questioned the wisdom of the Court of Queen's Bench even addressing the constitutional questions. ${ }^{42}$ This comment seriously undermines whatever precedential value the Court of Queen's Bench decision might otherwise have had.

Recently, the Alberta Court of Appeal decided a case in which the familiar situation of a challenge to the exclusion of non-status Aboriginal people from the benefits of being a status Indian was reversed. In Cunningham v. Alberta (Minister of Aboriginal Affairs and Northern Development), ${ }^{43}$ former members of the Peavine Métis Settlement, who had been removed from the settlement's membership list because they had registered as status Indians, challenged their exclusion on equality grounds. The Court of Appeal determined that the legislative exclusion of Métis individuals who were also registered Indians from membership in the Métis Settlements, despite their self-identification as Métis, was discriminatory according to the test established in Law. In coming to this conclusion, the Court of Appeal decided that the excluded Métis persons suffered unique disadvantages and stereotyping as being "less Métis" because of their exclusion from membership in the Métis Settlements. In determining that the differential treatment did not adequately correspond with the actual circumstances of the excluded Métis individuals, the court reiterated the point made by the Supreme Court of Canada in Law that when legislation excludes an already vulnerable or disadvantaged claimant group from a benefit, the purported correspondence is more closely scrutinized. ${ }^{44}$ Lastly, the Court of Appeal concluded that the legislative exclusion could not be justified under section 1 of the Charter not only because the legislation did not minimally impair the excluded individuals' equality rights, but because the purported objectives for the exclusion were not pressing and substantial and, even if any of them were, the exclusion was not rationally connected to those objectives. ${ }^{45}$

While these cases have addressed distinctions made on the basis of status, the case in which the status rules in the Indian Act themselves have come under the most direct attack is McIvor v. The Registrar, Indian and Northern Affairs Canada, ${ }^{46}$ which was decided by the British Columbia Court of Appeal in April 2009. In this case, Sharon McIvor and Charles Jacob Grismer (also the plaintiffs in the Grismer v. Squamish First Nation case discussed earlier) challenged the Indian Act rules for determining Indian status, which had been enacted by Bill C-31 in 1985. The complainants 
claimed that by incorporating the discriminatory pre-1985 regime into the post-1985 regime as the starting point for determining entitlement to status, Bill C-31 did not eliminate discrimination but continued the gender discrimination of the pre-1985 regime. ${ }^{47}$ While the federal government argued that the differential treatment was solely the result of events that occurred before section 15 of the Charter came into force, the Court of Appeal observed that continuing governmental action may violate the Charter, even if it began before the Charter came into force; it therefore did not accept the government's characterization of the situation..$^{48}$ In fact, the Court of Appeal concluded that, "the most important difference in treatment between Ms. McIvor's grandchildren and those of her male analogue was a creation of the 1985 legislation itself, and not of the pre-Charter regime."'49

In determining that Mr. Grismer had been denied a benefit of the law, the Court of Appeal also agreed that the right to transmit Indian status to one's child should be recognized as a benefit. Justice Groberman, for the court, commented that, "it seems to me that the ability to transmit Indian status to one's offspring can be of significant spiritual and cultural value." ${ }^{50}$ The Court of Appeal also agreed that Bill C-31 created differential treatment on the basis of the enumerated ground of sex..$^{51}$ Thirdly, the Court of Appeal determined that the differential treatment was discriminatory, commenting that,

The historical reliance on patrilineal descent to determine Indian status was based on stereotypical views of the role of a woman within a family... . The impugned legislation in this case is the echo of historic discrimination. As such, it serves to perpetuate, at least in a small way, the discriminatory attitudes of the past.

The limited disadvantages that women face under the legislation are not preserved in order to, in some way, ameliorate their position, or to assist more disadvantaged groups. None of the distinctions is designed to take into account actual differences in culture, ability, or merit..$^{52}$

Turning to the question of justification of the law under section 1 of the Charter, the Court of Appeal also concluded that the law could not be saved as a reasonable limit on equality. While the court agreed that preserving the rights of those who acquired Indian status and band membership before 1985 was a pressing and substantial governmental objective behind Bill C-31 and that the legislation was proportional to the objective it sought to 
serve, they did not consider the legislation to minimally impair the rights of the claimants. They concluded this because the legislation actually made the disadvantage of those in Mr. Grismer's situation worse, as compared to those who lost status because both the mother and grandmother were nonIndians, by reinstating the comparator group to full section 6(1) status while only reinstating those in Mr. Grismer's situation to section 6(2) status. ${ }^{53}$ The court also noted that,

[t]here are two obvious ways in which the violation of s. 15 might have been avoided. The 1985 legislation could have given status under an equivalent of s. 6(1) to people in Mr. Grismer's situation. Equally, it could have preserved only the existing rights of those in the comparator group. ${ }^{54}$

Thus, the Court of Appeal declared subsections 6(1)(a) and 6(1)(c) of the Indian Act to be of no force and effect, though it suspended this declaration for a year. ${ }^{55}$

In response to the British Columbia Court of Appeal's decision in McIvor, the federal government introduced Bill C-3 on 11 March 2010. This bill addresses the Court of Appeal's decision in the McIvor case by allowing those whose mothers were deleted from the Indian Register prior to 1951 by reason of marriage to a non-Indian to register and pass their Indian status onto their children..$^{56}$ It does not, however, completely remove discrimination against those whose female ancestors were discriminated against because of section 6(2) of the Indian Act, which creates a hierarchy of status and serves to limit the ability of some status Indians to pass status on to their children. Thus, litigation, because of its incremental nature, has not yet wiped the ongoing effects of gender discrimination out of the Indian Act even though the McIvor case constituted a significant victory for the equality of Aboriginal women,. Such a result will have to await victories for Aboriginal women and their non-status children in a number of subsequent cases currently being litigated or yet to be launched. Of course, the inconsistency in results and in the analysis within the decisions in the other cases in this category also demonstrate the difficulties with relying on litigation to drive desired policy outcomes. 


\section{Métis and the Quest for Recognition of Their Aboriginal Rights}

Métis in Canada have also made extensive use of the courts to gain recognition. Having been recognized in the text of our Constitution as an Aboriginal people, through their inclusion in section 35 of the Constitution Act, 1982, Métis have been using litigation to advance claims to Aboriginal rights and Aboriginal title. The most important case of the several cases, both decided and ongoing, in which Métis have claimed an Aboriginal right to harvest natural resources is $R$. v. Powley, decided by the Supreme Court of Canada in 2003. ${ }^{57}$ This case started with an Ontario Court (Provincial Division) decision in 1999, when a Métis father and son were charged with unlawfully hunting moose in an area of northern Ontario near Sault Ste. Marie. They challenged the charge on the basis that, as Métis, they had an Aboriginal right to hunt moose free from government regulation.

The Supreme Court decided that they did, indeed, have an Aboriginal right to hunt. The Court decided that Métis were a distinct Aboriginal people with their own customs and group identity, in addition to mixed ancestry. It also decided that the customs that had developed in Métis communities prior to "effective European control" of the regions in which Métis communities were situated, when European laws and institutions became dominant over Métis communities, were the source of Métis Aboriginal rights. ${ }^{58}$ The test that the court established for determining whether an individual had a Métis Aboriginal right is, essentially, a four-part test:

- whether the practice the individual was undertaking was a practice integral to the distinctive existence of an identifiable historic Métis community prior to effective European control;

- whether there is a current Métis community that retains a connection to the historic rights-bearing community, so that it is capable of being a rights-bearing community today;

- whether there is some degree of continuity in the community's practices from the period prior to effective European control to the present time, so that the practice that is claimed to be a right neither disappeared nor was 
extinguished; and

- whether the individual claimant, in addition to claiming Métis identity, has an ancestral connection to a Métis community and is accepted as a Métis by a modern, rights-bearing Métis community. ${ }^{59}$

If all of these elements can be proven, an individual would have an Aboriginal right to engage in the protected practice in the "traditional territories" used by the Métis community.

While Powley was a major victory for Métis, as it was the first time that the Supreme Court of Canada recognized that Métis have Aboriginal rights, it has generated as many questions as it has answered. Because of the incremental and fact-specific nature of judicial decisions, it is not yet clear, for example, in which parts of Canada rights-bearing Métis communities exist, what the extent of their traditional territories is, or who has the right to determine who is a member of a Métis community. In the absence of clear answers to these questions, governments continue to seek to limit the number of communities they recognize as Métis communities and the locations in which members of recognized Métis communities can exercise their Aboriginal rights. It will require additional cases, and therefore time, to develop answers to these and other questions.

A number of cases seeking to clarify the extent of Métis Aboriginal rights have been argued since the Powley decision and several have been decided. One potentially significant recent case is $R$. v. Goodon, from Manitoba.$^{60}$ In this case, a Métis person from Manitoba claimed a right to hunt ducks throughout the northwest of Canada. While the Provincial Court judge decided that the right to hunt that was being claimed had to be narrowed geographically, and therefore had to be characterized as a right to hunt in the vicinity of Turtle Mountain in southern Manitoba, he did decide that the relevant historic Métis community occupied all of southern Manitoba (and beyond), and that there remains a contemporary rights-bearing community in "southwest Manitoba." 61 This would seem to expand the notion of a Métis community geographically to encompass an entire region. The judge also looked at the particular history of southern Manitoba and, on the basis of that history, determined the period of effective European control to be 1870 to 1880 . This is much later than was identified for the area around Sault Ste. 
Marie in the Powley case, suggesting that the determination of effective European control will vary across Canada. ${ }^{62}$

On the other hand, Métis have not always been successful in their litigation. The Supreme Court of Canada decided the case of R. v. Blais ${ }^{63}$ at the same time as it decided Powley. In Blais, a Métis hunter claimed immunity from conviction for hunting deer out of season under Manitoba's Wildlife Act, as it infringed on his Aboriginal right to hunt for food under the Natural Resources Transfer Agreement. ${ }^{64}$ This particular case hinged on whether Métis were "Indians" for the purpose of the Natural Resources Transfer Agreement, and the court concluded that they were not. ${ }^{65}$

In addition, in 2007, the Manitoba Court of Queen's Bench decided, in the case of Manitoba Métis Federation v. Canada (Attorney General), ${ }^{66}$ that the Métis of Manitoba had no claim to Aboriginal title over any territory in the province of Manitoba. The Court's first step was to deny the Manitoba Métis Federation standing as a part in the action, though the individuals who had also brought the action were recognized as having standing. ${ }^{67}$ The Court then determined that the action could not be brought because the time limit for bringing such an action - that is, for collective relief for an alleged failure to provide a collective benefit - had long since passed, as the obligation was to those alive in $1870 .^{68}$ It is also interesting to note that part of the Court's rationale for this conclusion is that,

the residents at the time, or their leaders, would have known of their rights ... As they had demonstrated their willingness to litigate in respect of their rights, ... I do infer that they chose not to challenge or litigate in respect of section 31 and section 32 [of the Manitoba Act] knowing of the sections, of what those sections were to provide them, and of their rights to litigate. ${ }^{69}$

The Court then went on to conclude that the outcome of discussions between the Crown and Métis in the region was neither a treaty or even an agreement but simply an Act of Parliament, and that the Red River delegates who met with the Crown did not have the authority to make a treaty. ${ }^{70}$ Thus, the Métis of Manitoba could not assert a treaty right to land. Finally, after reviewing the jurisprudence on Aboriginal title, the court decided that the Métis plaintiffs had not proven that the Manitoba Métis met any of the three criteria for proof of Aboriginal title, those being exclusive occupation, title in common, and non-alienability of land. ${ }^{71}$ As well, because the Court 
came to this conclusion, it also concluded that the Crown did not owe the Métis any fiduciary duty. ${ }^{72}$ This decision, at the end of a long, and no doubt expensive, process of research and legal argument, speaks volumes about the uncertainty involved when one is left to advance one's claims for redress through the courts. Unfortunately, very few alternatives have been made available to the Métis by governments.

The Métis have also used the courts effectively to advance policy in the area of consultation and the accommodation of Métis rights claims. The Crown's duty to consult with, and potentially accommodate, Aboriginal and treaty rights claims, even prior to proof of a right, was firmly established by the Supreme Court of Canada's decisions in Haida Nation v. British Columbia (Minister of Forests) and Taku River Tlingit First Nation v. British Columbia (Project Assessment Director). ${ }^{73}$ The Labrador Métis Nation made use of these decisions in successfully arguing before the courts that they were owed a duty to be consulted.

In its decision in the Labrador Métis Nation v. Newfoundland and Labrador (Minister of Transportation and Works), the Newfoundland and Labrador Court of Appeal decided that the Labrador Métis Nation did have a right to be consulted, as their claim for Aboriginal rights was at least strong enough to trigger the duty to consult established in the Haida Nation and Taku River Tlingit cases. ${ }^{74}$ In the course of this case, questions of whether Labrador Métis Nation members were Inuit and therefore the holders of Inuit rights, or Métis and therefore the holders of Métis rights, and whether they had to prove which they were in order to claim Aboriginal rights was raised. However, the Court decided that,

definitive and final self-identification with a specific aboriginal people is not needed in the present circumstances before the Crown's obligation to consult arises. All the respondents had to do was establish, as they did, certain essential facts sufficient to show a credible claim to aboriginal rights based on either Inuit or Métis ancestry. The situation might be different if the right adversely affected only flowed from one of the Inuit or Métis cultures. But that is not the case. ${ }^{75}$

The conclusion in the Labrador Métis Nation case, in the aftermath of the finding in Powley that Métis have Aboriginal rights, clearly serves to advance the participation of Métis in resource management. Indeed, one 
effect of these cases has been that the Government of Canada, at least, has sought to engage Métis organizations in designing a process for fulfilling its duty to consult and accommodate potential Aboriginal rights-holders; presumably, guidelines for undertaking consultations with Métis will form part of the federal policy. This is a clear example of a situation in which judicial decisions have driven Aboriginal policy, at least at the federal level, in a way that benefits Métis. Unfortunately, as the Manitoba Métis Federation case illustrates, Métis cannot be assured of success in their Aboriginal rights claims.

\section{Conclusion - The Problem with Relying on the Courts?}

Despite the existence of different groups with different interests and (in many cases) different claims before the courts, Métis, non-status Indians, and Aboriginal women have all determined that litigation can be a useful strategy for achieving state recognition of their Aboriginality in the face of governmental intransigence. They have also been fairly effective at finding their allies in the courts and using them to advance their interests. Aboriginal women and First Nation members residing off-reserves have made effective use of equality rights to reverse some of the discriminations against them that were contained in the Indian Act, secure recognition of their identity as Aboriginal people, and secure their inclusion in the collective lives of the communities in which they are members. Métis and non-status Indian people have also used the courts to expand our understanding of Aboriginal rights and secure for themselves involvement in resource management decisions. While this is all to the good, the process of litigation is often long and costly, as a number of the cases reviewed above demonstrate, and even strong claims do not always result in successful outcomes in court. Thus, one would be right to ask, "Is having Aboriginal policy be the outcome of litigation really good enough in a society that prides itself on its commitment to justice?"

\section{(Endnotes)}

1. [1999] 2 S.C.R. 203. 
2. Ibid., para. 14 (per McLachlin and Bastarache, JJ.).

3. Ibid., para. 18 (per McLachlin and Bastarache, JJ.).

4. 2003 FCT 115, [2003] 4 F.C. 1133 (F.C.T.D.).

5. Ibid., para. 77.

6. 2005 FC 1030, [2006] 2 F.C.R. 24, [2005] 4 C.N.L.R. 161 (F.C.T.D.).

7. 2007 FC 878, [2008] 1 F.C.R. 795 (F.C.T.D.). While the case came before the Federal Court of Appeal in 2008, only the remedy of striking down the relevant provision of the Indian Act was appealed, not the substantive decision. See Canada (Attorney General) v. Esquega, 2008 FCA 182, [2008] 3 C.N.L.R. 115.

8. [2000] 1 S.C.R. 950.

9. Quotation from Corbiere in ibid., para. 59.

10. [1999] 1 S.C.R. 497.

11. Ibid., para. 68. See also, for example, paras. 67 and 72 for use of the term "more disadvantaged." Para. 72 is particularly important, as it clearly states that the ameliorative purpose or effect of legislation on a more disadvantaged group, not merely a disadvantaged group, is a factor in an analysis of whether discrimination has occurred.

12. Ibid. para. 86 .

13. Ibid. para. 90 .

14. 2003 FCA 473, [2004] 2 F.C. 108.

15. Ibid., paras. 30-33.

16. Ibid., paras. 36-39.

17. 2007 FC 1036, [2008] 1 C.N.L.R. 65 (F.C.T.D.).

18. It is worth noting that the Nation had received funding from the federal government for the purchase of school supplies and a school allowance for students prior to 2001. See ibid., para. 5.

19. Ibid., para. 9. 
20. Ibid., para. 11.

21. Ibid., para. 14.

22. Sandra Lovelace v. Canada, Communication No. 24/1977: Canada 30/07/81, UN Doc. CCPR/C/13/D/24/1977 (UN Human Rights Committee).

23. [2000] 1 F.C. 513, [2000] 1 C.N.L.R. 205 (F.C.T.D.).

24. Ibid., para 52.

25. Ibid.

26. A similar fact situation has given rise to an extremely lengthy piece of litigation, Sawridge Band v. Canada. This case began in 1986, when the Sawridge Band, Ermineskin Band, and Sarcee Band (now the Tsuu T'ina First Nation) challenged Bill C-31 amendments to the Indian Act as invalid because they abridge the Aboriginal and treaty rights of the bands and interfere with their freedom of association. There have been numerous decisions in this case, by both the Federal Court and the Federal Court of Appeal, on both substantive and procedural issues, but it has yet to be concluded at the time of writing.

27. 2006 FC 1088, [2007] 1 C.N.L.R. 146 (F.C.T.D.).

28. Ibid., para. 8 .

29. Ibid., para. 11.

30. Ibid.

31. Ibid.

32. Ibid., para. 46.

33. Ibid.

34. Ibid., para. 57.

35. Ibid., para. 72 .

36. Ibid., paras. 73-74.

37. Ibid., para. 83 .

38. [2007] 2 C.N.L.R. 261 (Sask. Q.B.). 
39. Ibid., para. 51 .

40. Ibid., para. 66.

41. R. v. Powley, [2003] 2 S.C.R. 207, 2003 SCC 43.

42. [2008] 3 C.N.L.R. 288 (Sask. C.A.), para. 47.

43. 2009 ABCA 239.

44. Ibid., paras. 41-43, 49.

45. Ibid., paras. 62-64, 66-67.

46. 2009 BCCA 153 (b.c.C.A.), appealing 2007 BCSC 827, [2007] 3 C.N.L.R. 72 (b.c.S.C.).

47. McIvor (b.c.C.A.), para. 11.

48. Ibid., paras 46, 48, 57.

49. Ibid., para 61.

50. Ibid., para. 71.

51. Ibid., paras. 83, 87. Justice Groberman did, however, comment, in obiter, that he found the proposition that section 15 of the Charter extends to all discrimination based on pre-Charter matrilineal or patrilineal descent to be "a dubious one" and questioned whether matrilineal or patrilineal descent could be considered an analogous ground. See para. 99.

52. Ibid., paras 111-12.

53. Ibid., para. 143.

54. Ibid., para. 156.

55. Ibid., para. 161.

56. Gender Equity in Indian Registration Act, (Bill C-3), subsection 2(3), available at http://www2.parl.gc.ca/HousePublications/Publication.aspx?D ocId $=4340270 \&$ Language $=$ e $\&$ Mode $=1 \&$ File $=30$.

57. Supra, note 40 .

58. Ibid., paras. 10-13, 17-18. 
59. Ibid., paras. 21-46.

60. 2008 MBPC 59, 234 Man. R. (2d) 278, [2009] 2 C.N.L.R. 278.

61. Ibid., paras. 20, 46-48, 58.

62. Ibid., paras. 68-69.

63. [2003] 2 SCR 236, 2003 SCC 44.

64. Ibid., para. 3.

65. Ibid., para. 42.

66. 2007 MBQB 293, [2008] 4 W.W.R. 402, 223 Man. R. (2d) 42, [2008] 2 C.N.L.R. 52, 165 A.C.W.S. (3d) 820.

67. Ibid., paras. 405-407.

68. Ibid., paras. 442-47.

69. Ibid., paras. 445-6.

70. Ibid., paras. 464, 507.

71. Ibid., paras. 589-90.

72. Ibid., para. 631.

73. 2004 SCC 73, [2004] 3 S.C.R. 511; 2004 SCC 74, [2004] 3 S.C.R. 550.

74. 2007 NLCA 75, 33 c.e.L.R. (3d) 220, [2008] 1 C.N.L.R. 48, 830 A.P.R. 178, 272 Nfld. \& P.E.I.R. 178, 288 D.L.R. (4th) 641, paras. 50-53.

75. Ibid., para. 39.

\section{References}

Clifton v. Hartley Bay (Electoral Officer), 2005 FC 1030, [2006] 2 F.C.R. 24, [2005] 4 C.N.L.R. 161 (F.C.T.D.).

Corbiere v. Canada (Minister of Indian and Northern Affairs), [1999] 2 S.C.R. 203. 
Cunningham v. Alberta (Minister of Aboriginal Affairs and Northern Development), 2009 ABCA 239.

Esquega v. Canada (Attorney General), 2007 FC 878, [2008] 1 F.C.R. 795 (F.C.T.D.).

Francis v. Mohawk Council of Kanesatake, 2003 FCT 115, [2003] 4 F.C. 1133 (F.C.T.D.).

Gender Equity in Indian Registration Act, S.C. 2010, c. 18.

Grismer v. Squamish First Nation, 2006 FC 1088, [2007] 1 C.N.L.R. 146 (F.C.T.D.).

Haida Nation v. British Columbia (Minister of Forests), 2004 SCC 73, [2004] 3 S.C.R. 511.

Labrador Métis Nation v. Newfoundland and Labrador (Minister of Transportation and Works), 2007 NLCA 75, 33 c.e.L.R. (3d) 220, [2008] 1 C.N.L.R. 48, 830 A.P.R. 178, 272 Nfld. and P.E.I.R. 178, 288 D.L.R. (4th) 641.

Law v. Canada (Minister of Employment and Immigration), [1999] 1 S.C.R. 497.

Lovelace v. Ontario, [2000] 1 S.C.R. 950.

Manitoba Métis Federation v. Canada (Attorney General), 2007 MBQB 293, [2008] 4 W.W.R. 402, 223 Man. R. (2d) 42, [2008] 2 C.N.L.R. 52, 165 A.C.W.S. (3d) 820.

McIvor v. The Registrar, Indian and Northern Affairs Canada, 2007 BCSC 827, [2007] 3 C.N.L.R. 72 (b.c.S.C.).

McIvor v. The Registrar, Indian and Northern Affairs Canada, 2009 BCCA 153 (b.c.C.A.). 
Micmac First Nation v. Canada (Minister of Indian and Northern Affairs), 2007 FC 1036, [2008] 1 C.N.L.R. 65 (F.C.T.D.).

Misquadis v. Canada (Attorney General), 2003 FCA 473, [2004] 2 F.C. 108.

Ochapowace Indian Band v. Saskatchewan (Department of Community Resources), [2007] 2 C.N.L.R. 261 (Sask. Q.B.).

Ochapowace Indian Band v. Saskatchewan (Department of Community Resources), [2008] 3 C.N.L.R. 288 (Sask. C.A.).

R. v. Blais, [2003] 2 SCR 236, 2003 SCC 44.

R. v. Goodon, 2008 MBPC 59, 234 Man. R. (2d) 278, [2009] 2 C.N.L.R. 278.

R. v. Powley, [2003] 2 S.C.R. 207, 2003 SCC 43.

Scrimbitt v. Sakimay Indian Band Council, [2000] 1 F.C. 513, [2000] 1 C.N.L.R. 205 (F.C.T.D.).

Taku River Tlingit First Nation v. British Columbia (Project Assessment Director), 2004 SCC 74, [2004] 3 S.C.R. 550. 